\title{
THE RADICAL LEFT IN COALITION GOVERNMENT: TOWARDS A COMPARATIVE MEASUREMENT OF SUCCESS AND FAILURE
}

\author{
Richard Dunphy and Tim Bale
}

\begin{abstract}
This article raises questions about how best to assess the performance of radical left parties participating in coalition governments. Drawing in part on interviews, it covers parties that have participated in coalition government (Cyprus, Finland, France, Ireland, Italy, Norway), or have acted as 'support parties' (Denmark, Sweden), or are debating the 'pros and cons' of coalition participation (Netherlands). It undertakes a comparative analysis of how radical left parties themselves evaluate the measure of their achievements and failings in coalition government - a critical exercise for such parties that can influence their tactical and strategic decisions about future government participation, as well as the ability of the parties to survive political and electoral setbacks. The approach we adopt is one that takes the policy, office and votes triad developed by political scientists seriously, but also factors in the principles, political outlook and goals of the parties themselves. It concludes that the experience of coalition government for radical left parties is far from encouraging to date. Their few achievements have to set against many potential pitfalls. Whilst there may be no alternative to government participation if these parties wish to be taken seriously as actors, a more strategic and cautious approach to coalition formation seems advisable in many instances.
\end{abstract}

$\underline{\text { Key words: radical left parties, government, coalition, policy, office and votes }}$

In recent years, parties to the left of mainstream social democracy have either stabilised their share of the vote or staged moderate-to-impressive recoveries in a number of European countries (Cyprus, Germany, France, Netherlands, Norway, Denmark, Finland, for example). Elsewhere (as in Italy), the radical left has taken a disorientating electoral hammering. These shifting electoral fortunes have coincided with, and in part of course reflected, two other developments. The first development is the emergence of new radical left parties that, in various ways, transcend the old division of the left into the 'party families' of communists, social democrats and greens: examples include, the Nordic 'red/green' left parties, the Dutch Socialist Party, the German Left Party, the Portuguese Left Block, the French New AntiCapitalist Party, and the Greek Coalition of Left and Social Movements. The second development is the increasing 'availability' of radical left parties as potential parties of (coalition) government.

Apart from the immediate (but short-lived) post-War inclusion of communist parties in some western European coalitions, and the anomalous case of Finland, the radical, anti-capitalist left was effectively excluded from government participation for four decades. Since the early 1990s, however, parties to the left of social democracy have participated in government in Finland, Norway, Iceland, France, Italy, Ireland, and Cyprus. Their successes and failures - including their own perceptions of the experience - have been hotly debated within some of the other left parties that are drawing closer to potential government participation (for example, in Sweden, Denmark, Germany, and the Netherlands.). Widely differing evaluations of the experience of government participation have been at the heart of recent convulsions on the Italian radical left.

Elsewhere, we have argued that the time is ripe for academics to stop treating radical left parties as 'niche' players that are less interested in, and less suited for, 
government office than other, more 'mainstream' parties, and instead to 'bring them in from the cold' (Bale and Dunphy, 2007; see also Hough and Verge, 2009). Specifically, we have argued that the 'policy, office and votes' schema developed by Müller and Strøm (1999) can be utilised to explore the 'hard choices' made by radical left parties on government participation; and that many of the differences between how left parties and how other types of parties handle decisions on government participation are differences of degree rather than of kind. We would not wish, however, to suggest that radical left parties are indistinguishable, either in their tactical and strategic behaviour or in the pressures they face, from, for example, social democratic parties; or that ideology and idealism are not important variables in their own right. Path dependency (for example, a history of exclusion, or a background as a party of protest and oppositionism) and institutional factors (for example, the fact that many are small rather than large parties), both have an important role to play in elucidating how left parties might view government participation. So, too, though does the transformatory vision of society and of politics that many of these parties hold - indeed it is this vision which, one might argue, defines them as 'left' parties in the first place. It is our contention that ideology still has an important role to play for the radical left, and that these parties' evaluations of their own successes or failures in government deserve to be taken seriously.

\section{Terminology and Case Selection}

March and Mudde (2005: 24) remark that using terms like 'radical' and 'left' to describe the parties they focus on is to enter a 'potential terminological minefield.' Mindful of such considerations, we would argue that 'radical left' or possibly 'anticapitalist left', are the labels best suited to the parties we are studying. Certainly, the old distinction between 'reformist' and 'revolutionary' is less than helpful nowadays, especially as reformist has often been held to be synonymous with being both supportive of liberal democracy and reconciled to the capitalist system, while revolutionary has often been held to imply that a party is intent, more or less openly, on the (possibly violent) destruction of both multi-party democracy and capitalism. Almost twenty years after the Soviet collapse and the end of the Cold War, such thinking is highly dated. Apart from a few 'nostalgics', such as the Greek Communist Party (KKE) and the Portuguese Communist Party (PCP), which almost exclude themselves from the compromises of real coalition politics, all of the radical left parties that have a chance of government participation in western Europe are thoroughly committed to liberal democracy, even if have criticisms of it as presently practised. The parties we examine remain both radical and left - and to the left of social democracy - in the triple sense suggested by March and Mudde (2005: 25): they identify the major causes of the crisis of faith in representative, liberal democracy as rooted in chronic inequality and social injustice; they do not accept the capitalist system as the final stage in human development, but view it as a transitional phase towards a more just and rational way of managing human affairs - and continue to propose economic and social policies and solutions to problems that 'buck the trend' of dominant neo-liberal thinking; and they are profoundly internationalist in their political outlook. 
Above all, it is the belief that a left politics must inspire and maintain the possibility of long-term transformation that distinguishes radical left parties from social democratic parties. Of course, the biggest challenge such parties face is precisely that of combining idealism, first with policies that move beyond slogans appealing to a dwindling traditional support base and second, with the trials and compromises that participation in government inevitably involves. Naturally, this is where radical left parties can come unstuck. It can be very difficult to maintain longterm transformation as a living, convincing aspiration when the participation of one's party in government furnishes scant or modest evidence of movement forward.

The present survey focuses on radical left parties from multiple backgrounds, which broadly speaking share the characteristics listed above and which have varying degrees of coalition governmental experience, or are at least potential partners in coalition governments in the foreseeable future. Finland's Left Alliance (VAS, in government from 1995 until 2003) and Sweden's Left Party (V, not yet in government, but with experience of providing external support and with aspirations to government participation) both grew out of the communist movement, but neither considers itself a (post-)communist party nowadays; both see themselves as 'greenleft' or 'red-green' parties. So, too, does Norway's Socialist Left (SV, in government since 2005), which grew out of the left-wing of social democracy, and Denmark's Socialist People's Party (SF - in a similar position to the Swedish Left Party), which has its roots in a merger between left-social democrats and reform-minded communists. Ireland's Democratic Left (DL - in government from 1994 to 1997) grew out of the communist-style Workers' Party, and did not survive its spell in government, merging with the Labour Party at the end of the 1990s. The Netherlands Socialist Party (SP - not yet in government, but involved in unsuccessful negotiations following the 2006 general elections) grew out of the Maoist tradition, but is now thoroughly 'de-Bolshevised', if still radical, activist and anti-capitalist. Cyprus's Progressive Party of Working People (AKEL - dominant party in government currently) still considers itself to be a communist party, a do the French Communist Party (PCF - in government from 1995 to 1997) and the two Italian communist parties (PRC and PdCI - in government most recently from 2006 until 2008).

\section{Reflecting on Government Participation: what constitutes Success and Failure?}

The 'policy, office and votes' triad, developed by Müller and Strøm, is a useful place to start. As with other types of parties, and especially with other small parties, the radical left parties face difficult decisions about, and trade-offs between policy implementation (or lack thereof), getting into government, and vote maximisation. Has the party in question achieved clear implementation of key policies? Can it claim credit for policy achievements, or is credit likely to go to, for example, a larger social democratic partner? If the party's main policy achievement is 'negative '- for example, preventing a more pronounced drift towards neo-liberalism - can it articulate this achievement to voters convincingly? Did the party achieve the cabinet positions that would have enabled it to implement its minimal demands? Has government participation consolidated its vote or led to electoral losses? 
But there are other considerations beyond the familiar triad that reflect more specifically the ideological concerns of the radical left, as well as its historical trajectory in recent years. One such consideration is whether assuming office has helped to legitimise the party and remove any lingering Cold War era suspicion of the democratic credentials of the radical left? Another is that of reinvigorating the party format so as to preserve the party as a credible vehicle of social and political transformation. This may involve evaluations of the party's participation in government in terms of how the experience has impacted on party unity, ideological credibility, and the ability to satisfy members' and voters' expectations of social and political change - has the party had to choose between these goals and to risk a split or a loss of idealism? Has it risked a (perhaps fatal) loss of identity by becoming too closely associated with its larger coalition partners, especially the social democrats? Has government participation impacted on the party's relationship with progressive social movements and, in particular (if it sees itself as part of the wider movement against neo-liberal globalisation and as the harbinger of a new type of participatory politics) on its credibility with the anti-globalisation movement? Are there key social groups - core voters, or trade unions, for example - with which a small party of the radical left dare not risk loss of purchase?

Another measure of success or failure may well be whether the party has managed to carry out a successful generational and leadership renewal while preserving its identity, or has it risked absorption by the institutions of government in which it is now participating? For example, for some small radical left parties, the first experience of participation in government can see virtually the entire top tier of party leadership absorbed in government business with little time, resources or energy left for the task of party-building and party maintenance. This can lead, or contribute, to party atrophy. For some parties, the first taste of government office can attract new potential cadres to the party. Some parties fear attracting careerists, opportunists or 'moderates' and either place obstacles in the way of their selection as candidates or insist upon rigorous socialisation into the culture of the party. Others may welcome incomers as an essential, and long-overdue, infusion of new blood.

Greater involvement in the institutions of government may also mean heavy dependence on those party leaders appointed to cabinet office. This may mean that a radical left party's public persona - its very perception by members and voters and the wider public - becomes reduced to media portrayal of the views of a tiny group of leaders. These leaders, in turn, whilst developing a taste for government office, may find themselves less tolerant of internal criticism from within the party ranks about policy or presentation shortcomings. If a radical left party remains true to its declared aim of using government office as a means to achieve social transformation rather than an end in itself, and if it wishes to avoid assimilation by a larger partner, there may well come a point at which it prefers to withdraw from office. At this point, can party structures and traditions cope with greater vulnerability to shocks (such as the defection or loss, or feared loss, of a charismatic leader)?

For radical left parties, one very positive outcome of government participation may well be the removal of the residue of the popular view that such parties are purely for protest and not for governing - that they are either 'unsuitable' for government office because of lingering Cold War anti-communism and the myth that 
socialism is incompatible with Western democracy (which, in turn, is seen as synonymous with capitalism); or that they are the vehicle of undisciplined idealists who will inevitably disrupt and undermine any coalition government that they are invited to join. Successful participation may, in other words, enhance the democratic legitimacy of the party and consolidate its reputation as a force for practical change as well as long-term vision. Successful participation, then, may play a role in moving the axis of the political system to the left as the radical left is revealed as a positive force in government. Conversely, a failure to maintain the balance between steady and reliable participation and fidelity to membership beliefs and expectations can prove disastrous in a variety of ways, from paralysing the party through internal divisions to sacrificing party identity on the altar of democratic legitimacy to the point where its ministers are widely praised as effective politicians, while the party itself withers on the vine.

Finally, a measure of success or failure for the radical left is undoubtedly whether or not government participation leads to greater and fairer coverage in the mass media. Given the overwhelmingly reliance of modern politics on the mass media, and the dearth of mass-circulation newspapers (and indeed television and radio stations) sympathetic to the radical left; and given what small parties in general, and the radical left in particular, perceive as biased reporting and under-reporting of their views, a more positive media image that transcends past stereotypes and stigmas would undoubtedly be an achievement.

Let us now examine each of these sets of criteria in more depth. We should of course bear in mind that government participation is a very recent phenomenon for some radical left parties, and an as yet unrealised possibility for others; therefore only short-term effects or anticipated outcomes will tend to be available for analysis at this stage. But we should note also a growing tendency for these parties to share experiences and analyses, to seek to learn explicitly from each other's experience in respect of government participation. This has involved not only reports to each other's party conferences, but also summer-school-style gatherings at which coalition formation is discussed. In such ways, the radical left is itself developing a comparative awareness of the costs and the opportunities associated with government participation.

\section{Policy, office and votes}

Given that left parties often put as much of a premium put on arresting the progress of neo-liberalism as they do on the positive promotion of their own policies, and given that those parties are relatively small, we need to be careful not to be too dismissive if few of their schemes loom large in the programmes of the governments they join or support. That said, the concrete achievements chalked up by most left parties to date can still only be called modest. Even the most optimistic supporter would be hardpressed, firstly, to prove beyond doubt that certain measures would not have been passed anyway - the employment measures of the Jospin government in France are an obvious example - and, secondly, to argue that they represented a significant step on the road towards socialism or saving the planet. True, as in Norway, some valuable conservation land was protected from oil and gas exploration and exploitation 
(Solhjell interview). But mostly we are talking about small changes: a subsidy or welfare service saved from (more drastic) cuts here (Siimes interview, Linden interview), a benefit rate marginally increased there - measures that shouldn't be sniffed at in terms of their impact on real people in real predicaments but, still, little that could be trumpeted at election-time as proof positive that the left party really was turning dreams into realities. No wonder the lists of achievements publicized by left parties often smack of defensiveness. On the other hand, blowing one's own trumpet is clearly essential. We know how frustrated support parties get at the tendency for larger parties in government to claim credit for measures that they suggested (Bale and Bergman 2006a); judging from left parties' experiences, becoming a full-blown coalition partner does little to resolve this particular problem.

For small radical left parties knowing which policy compromise is a step too far, and knowing when, and under which conditions, to leave a coalition may indeed be a vital part of the survival process. Some parties have drawn the conclusion that government participation (a) should be on the basis of a clear programmatic agreement (such as the Soria Moria agreement in Norway) to which the party can subsequently point (Kox interview, Thorkildsen interview); (b) should specify certain core demands, failure to deliver on which would constitute grounds for leaving the government (Arhinmaki interview, Leijten interview); or (c)should ideally involve the capture of certain strategic cabinet portfolios, such as the Finance Ministry (Linden interview, Lysbakken interview). For the Norwegian SV, an ongoing process of marking up certain government policies as SV achievements, to distinguish it from the Labour Party in the next elections, is an essential part of government participation (Solhjell interview). Yet this did not prevent Labour from benefitting most from the coalition arrangement and out-manoeuvring SV in the 2009 elections. The three-party left coalition government was narrowly returned to office, but Labour was the only party to gain votes and seats, with SV falling from 8.8 per cent to 6.1 per cent.

In the single case where the radical left party is the dominant partner in government - AKEL in Cyprus - it has to date followed relatively moderate, even social democratic policies in office. Yet AKEL can scarcely be expected to 'walk out' on itself. AKEL has - like the PCI in Italy (see Kertzer, 1996: 154) - warded off accusations of deradicalisation by maintaining strong symbolic continuity with its communist past, a matter of some importance to its mass membership and thousands of activists (Kiprianou interview). Whether this symbolic and ritualistic affirmation of belief in the long-term transcendence of capitalism would afford party elites in other countries the considerable political leeway that AKEL's leaders still enjoy is another matter (See Dunphy and Bale, 2007).

As regards office, given their history of exclusion from power, it is hardly surprising that a major aim of radical left parties on first reaching government office is to show that they can handle it and stay the course. To this extent they have clearly succeeded, even if some have paid a price in terms of loss of identity and of voters. All of the left parties involved in governing have to date demonstrated that they could stay the course and, for the most part, deliver their MPs and their agreed commitments even if this involves some sacrifice. Where they were part of fullblown coalitions (for example in Finland, Ireland and France) their ministers were almost invariably seen by their colleagues from other parties, and by those members 
of the general public who had heard of them, as competent professionals rather than boat-rocking radicals or people out of their depth. The arrival in office of these ministers saw no sign of the systematic disarray that, for instance, marked the arrival of radical right-wing populists as ministers in Austria and the Netherlands. Certainly, in both France and Finland, left party ministers were seen as more reliable than their Green colleagues (Szarka 1999).

Whether demonstrating their ministerial competence means that they will be entrusted with office in the future remains to be seen. In Finland, where they have been in a position to be asked again, the record is mixed. VAS's first term was immediately followed by a second, again at the invitation of the Social Democrats. Despite having to sign up to an austerity programme and internal divisions in the parliamentary group during the first term in office, by 1999 the party as a whole had actually come round to the idea of being in government and the vote in the party board for re-entering the government saw a more convincing majority. Meanwhile, the party was able to put together a more coherent set of priorities for coalition negotiations and secured itself more impressive portfolios. And, once again, it stayed the course - unlike the Green Party, which walked out of the government in 2002 in protest at its decision to build new nuclear power stations. But in 2003 (third time round) VAS was passed over, much to the disappointment and surprise not just of its of leaders, but also its activists and members who were by then more reconciled than ever to the government role. Its omission was largely down to the new formateur, the Centre Party, though whether the Social Democrats, who lost the premiership but continued in government, could have done more to insist on its former partner being kept on board is a moot (and sore) point. But it is also one that feeds into debate on the future of the party since, even with a change of leader, VAS remains on the horns of a dilemma: take a harder line against social democratic compromises in pursuit of votes or tone things down so as not to blow any chance of being invited back into government next time around. It says much about the contemporary orientation of the party, however, that the bitterness of this internal debate after 2003 resulted not from the strains of office but from surprise and disappointment at being denied it (see Dunphy, 2007).

Van Spanje (2007: 36) argues, not unreasonably, that 'participation in government can have a devastating electoral effect on radical parties.' In fact, government participation has not yet been disastrous for the radical left (except in Ireland, where modest losses nevertheless contributed to a collapse of morale, and Italy, where severe losses led to the complete removal of radical left parties from parliament for the first time since 1945). But nor, as Table 1 shows, has it found some magical formula that will allow it to escape the incumbency losses which, research shows, are increasingly the lot of any party that goes into government. In some cases these losses were marginal, as in Cyprus, Finland, Greece and Ireland, possibly because in those countries there were as yet no credible alternatives on the left - or indeed on the populist radical right - that disillusioned 'purists' or dissatisfied 'globalisation losers' could vote for. This is no longer the case in Ireland (where Sinn Féin has risen to fill the vacuum left by the dissolution of DL), or in Finland where VAS faces competition from both the Greens and the populist right-wing True Finns party). In France, where those alternatives - on both the extreme left and extreme 
right - were clearly available, the losses were more serious, and not offset by a slightly half-hearted attempt by the PCF's leader and presidential candidate, who was not himself a minister, to emphasize the party's separate identity as elections approached. On the other hand, the losses experienced in 1997 were hardly worse than those experienced in 1986, two years after pulling out of its coalition with the socialists in protest against the U-turn on public spending. In Italy, the experience of government participation from 2006 to 2008 proved disastrous for the radical left. In the 2008 elections, the two communist parties, the Greens and some left-socialists presented a common electoral list called 'The Left - Rainbow'. The total vote for the radical left collapsed from around 11\% (Communists and Greens combined) in 2006 to just over $3 \%$ in 2008 , and not a single radical left representative was elected to parliament. In Norway, there were no credible alternatives to SV on the left in 2009. However, a desire to keep the right from power may have encouraged some SV voters or shift their votes to Labour.

Table 1: Left party vote share immediately before and after government participation

\begin{tabular}{|l|c|c|c|}
\hline Country & $\begin{array}{l}\text { Election immediately } \\
\text { preceding first period } \\
\text { in office } \\
\mathbf{( \% )}\end{array}$ & $\begin{array}{l}\text { Election(s) } \\
\text { immediately } \\
\text { following period in } \\
\text { office }\end{array}$ & $\begin{array}{l}\text { Election(s) immediately } \\
\text { following subsequent } \\
\text { period(s) in office } \\
\mathbf{( \% )}\end{array}$ \\
\hline Cyprus & $34.7(2001)$ & $31.1(2006)$ & $\mathrm{n} / \mathrm{a}$ \\
\hline Finland & $11.2(1995)$ & $10.9(1999)$ & $9.9(2003)$ \\
\hline France* & $9.9(1997)$ & $4.8(2002)$ & $\mathrm{n} / \mathrm{a}$ \\
\hline Greece** & $11.0(1989)$ & $10.3(1990)$ & $\mathrm{n} / \mathrm{a}$ \\
\hline Iceland & $21.7(2009)$ & $\mathrm{n} / \mathrm{a}$ & $\mathrm{n} / \mathrm{a}$ \\
\hline Ireland & $2.8(1992)$ & $2.5(1997)$ & $\mathrm{n} / \mathrm{a}$ \\
\hline Italy*** & $8.6(1996)$ & PRC $-5.0(2001)$ & $\begin{array}{c}\text { PRC }-5.8(2006) \\
\text { PdCI }-2.3(2006)\end{array}$ \\
& & PdCI $-1.7(2001)$ & $3.1(2008)$ \\
\hline Norway & $8.8(2005)$ & $6.1(2009)$ & $\mathrm{n} / \mathrm{a}$ \\
\hline
\end{tabular}

\footnotetext{
*Figure is given for PCF. The MDC (now MRC) took 1.2 and 1.1\%. The PCF supported, though did not join, a centre-left government between 1989 and 1993. But it joined the Jospin government in 1997, as did the MDC - a vehicle for the leftist-nationalist Jean-Pierre Chevènement. While the latter quit the government in 2000, the PCF stayed the course.

** KKE and Synaspismos fought these elections together before diverging shortly after.

*** Rifondazione Comunista (PRC) supported the centre-left government between 1996 and 1998, when the party split. The PRC withdrew support but the smaller splinter party, Partito dei Comunisti Italiani $(\mathrm{PdCI})$, took up the offer of a place in government. Both took cabinet seats when a new centreleft government was formed in 2006. The two Italian communist parties, the Greens and some other left-socialists fought the 2008 elections on a common platform - 'The Left - The Rainbow'.
}

\section{Organisational integrity}


With the exception, of Ireland and Italy, left parties have survived getting into government or providing a minority administration with a parliamentary majority. Party unity, however, tends to come under severe strain. Although the tradition of democratic centralism persists in Cyprus, many left parties now pride themselves on their openness and tolerance of dissenting voices. Activists and MPs who feel that the party in government is compromising its long-term goals or ideology are usually free to give expression to their views. Often, this involves playing a double game - joining (or supporting) a government that will give them access to power, but criticising and demonstrating against government measures they don't like in order to maintain radical credentials and party mobilization. The latter strategy may provoke the ire of coalition partners or the minority government being supported, as well as the ridicule of media outlets more than happy to undermine the claims to credibility and responsibility of left party leaders. Just as importantly, it undermines those leaders, especially those who are ministers and therefore subject to collective cabinet responsibility. This happened very early on in Norway, for instance, when SV parliamentarians were lambasted for joining a protest against the government's foreign policy that took place in the grounds of the Storting. And it happened in spite of the fact that in Norway (as in Finland) there were people in the party who had learned from the French experience that this kind of double-game is ultimately selfdefeating: That it is 'better to admit to having to make compromises and take any ensuing criticism on the chin than to try unconvincingly either to disassociate oneself from them or to sell them as victories' (Solhjell interview). It might also be added that attempting to play the role of 'opposition in government' lacks credibility unless the party in question has a clear 'line in the sand' beyond which it will not be pushed. Lack of experience and relief at having achieved office both militate against this. In Finland, VAS ministers were criticized by their own left-wing for allowing themselves to be 'pushed and pushed and pushed' (Arhinmaki interview). In Italy, the PRC was badly split and damaged by a decision to bring down the first centre-left government in the late 1990s; and split and damaged again by divisions over whether to quit and how to evaluate the performance of a subsequent centre-left government in 2006-8.

For many, it is not just internal party democracy that comes under severe pressure. An activist tradition - of expanding democratic participation beyond the narrow constraints of parliament, and of constant involvement in community and social movement activism - is an important hallmark of the radical left. It can be difficult to maintain this when in government. For the Dutch SP, 'if we go into national government, it will be very important to maintain contact with the people and have out role in government subject to constant scrutiny by the people. It's a good thing to have all kinds of protests to remind you when you're not doing a good job' (Kant interview). It remains to be seen if this culture of radical activism and protest politics is really compatible with government participation; or if periodic withdrawal from government and re-immersion in activism is necessary to maintain a radical identity. The latter, of course, carries problems of credibility.

While increased electoral success brings an infusion of new blood into the ranks of the parliamentary group and party leadership, it can also bring challenges. As Nicole Bolleyer (2008: 18) has demonstrated, the costs of government office can 
often be higher for new parties than for long-established parties, one of the reasons being that the newly-acquired experience of government participation can create functional pressures and internal organizational strains that are especially acutely felt by parties that have not yet fully institutionalized their structures. Many of the parties we are examining are fairly new parties and their experience often tends to support Bolleyer's arguments. Government participation (and, indeed, the preparations and negotiations that precede this) tend to encourage a shift in power from a party executive or board, usually elected by an activist-dominated congress, to the parliamentary group; this can cause tensions. Government participation almost always increases this tendency as decisions have to be taken rapidly by leadership elites. Whilst believing fully in multi-party representative democracy, radical left parties insist that democracy cannot be reduced to the parliamentary arena alone; it requires a strong civil society. This, in turn, requires strong extra-parliamentary activism. Radical left parties struggle with this contradiction: how to combine parliamentary effectiveness with efforts to avoid top-down domination by the parliamentary group. Some have introduced measures such as paying MPs a worker's wage as a deterrent to careerism or have tried to use policy forums involving MPs and elected party bodies as a way of avoiding policy monopolization by MPs. Others agonise over how to handle increased success. After the 2006 elections, when the Dutch SP increased its number of MPs from 9 to 25, the party admits that it spent the next year absorbed in introspective debate about how to 'manage' the challenges of increased electoral appeal: 'we took a year out for internal reflection' and were 'less visible' is how the party leader put it (Marijnissen, 2008).

For some radical left parties maintaining good and close relations with the social movements - for example, anti-war, feminist and anti-capitalist movements - is an essential goal, and jeopardizing these relations in government might be seen as a measure of failure (Hoffman interview). For others on the left, maintaining good relations with traditional parts of the left electorate such as the trade unions is vital. In Finland, the unions played a vital role in facilitating VAS's entry to government in 1995, acting as intermediaries between VAS and the Social Democratic leadership (Hynonen interview) and trade union leaders within the party have remained amongst the strongest advocates of an early return to government. For Norway's SV, a lesson to be learnt from the French experience is that government participation without strategic vision and with too many policy compromises cost the PCF the support of trade unionists (Lysbakken interview). Certainly, the Italian left was furiously attacked by some within the social movements for following policies in government between 2006 and 2008 that were anathema. Indeed, the PRC's move to the left under its newly elected leader Paolo Ferrero, even if it risks ruling out government participation for the foreseeable future, could be seen as in part an attempt to repair the damage inflicted on this relationship. But it also provoked a walkout by those who maintain that the radical left has to present itself as a credible coalition partner for the Democratic Party if the right is ever to be defeated - a move which led to the creation of the rival Left and Liberty (SL) list for the 2009 European elections.

Another obvious problem posed by participation by the radical left concerns the extent to which, as a government or a support party, resources are devoted to keeping up with current executive and legislative concerns rather than to long-term 
political education and strategic thinking, as well as to strengthening or just maintaining organisational capacity. Indeed, party organisation may be seriously undermined if available full-time personnel are moved from party headquarters to act as support staff for the ministerial team. Obviously, institutional factors - such as the degree of state financial support available to the party to run its organisation -are important here.

In the case of the Irish Democratic Left, for instance, government participation from 1994 to 1997 saw 4 of its 6 parliamentary deputies allocated ministerial posts (two in the cabinet and two junior ministers), and party headquarters was effectively denied the human resources needed to engage in party-building as 'most experienced paid party workers were reallocated to the job of defending government policy and servicing the party in government' (Connell interview). Ultimately, the Irish DL did not survive the experience, merging with Labour shortly after leaving government (see Dunphy, 1998). Part of the deal with Labour that the leadership was anxious to secure was that Labour would assume responsibility for DL's mounting financial debts (O’Connell interview) - a not inconsiderable problem for a small and newly formed party that not only had suffered an electoral setback but had had insufficient time to carve out an effective extra-parliamentary identity and infrastructure.

Other radical left parties have seen government participation pose similar types of challenge. In Norway, entry into government in 2005 saw virtually the entire leadership of the party in government. For three months there was no party secretary and extra-parliamentary organization suffered badly (Heidar interview). To maintain the unity and mobilization of the party - given that many members will have had reservations about government participation in the first place - greater attention to organizational matters and to communication with the membership about government policy is surely a necessity for radical left parties.

\section{Legitimacy and acceptance}

There can be no doubt that many radical left parties see government participation as ending their ostracism within the political systems of western Europe; and that this acceptance of their full legitimacy as democratic actors is hailed as a significant success. When Oliviero Diliberto, now leader of the PdCI, first accepted office as Minister of Justice in the centre-left government in Italy, he made much of the fact that he now sat at Palmiro Togliatti's old ministerial desk - Togliatti had held the same post at the end of the Second World War until the PCI were forced from office with the onset of the Cold War. The symbolic link to the period when the PCI was at the height of its legitimacy is obvious. Norway's SV clearly hopes that its performance in government since 2005 means it is now an accepted coalition option, as well as a sign to voters that increased pluralism on the left is not necessarily destabilising. Former Danish SF leader Holger Nielsen, explaining that the party looks forward to entering government in Denmark after the next elections, argued that such a move would finally break down Social Democrat beliefs that they alone were the party of the left and mark the beginning of a new pluralism on the left (Nielsen interview). There is, of course, an in-built paradox here. In order to convince the Social Democrats that their inclusion in government can no longer be avoided, the 
radical left has to maximise its votes by competing vigorously. But too vigorous an attack on the Social Democrats may make coalition negotiations more difficult; and especially during and after a spell in office, ongoing attempts to distinguish themselves clearly from the Social Democrats by attacking aspects of Social Democratic policies may have a destabilising effect on government and lead to accusations of 'irresponsibility'. There may be an inherent trade-off, in other words, between increased legitimacy and political distinctiveness, as indeed the Italian experience shows. And, of course, as we have seen from Finland, there is no guarantee that the Social Democrats will invite the left party into a future coalition government.

Legitimacy may well be a necessary goal for the radical left in countries where the far right has had access to government office (de Lange, 2007). In the Netherlands and Italy, for example, where far right parties preaching a message which the left considers inimical, not just to its own values but to democracy as a whole, have enjoyed the fruits of office, exclusion is keenly felt. In such cases, establishing the party's governing credentials and its ability and right to play a full role in national politics acquires a special sense of urgency. In this context, achieving office risks becoming a goal in itself, irrespective of the compromises, sacrifices and even the existential threats that it would entail.

We should also note that the mere fact of government participation is seen as a success story in itself by those parties that have had the experience of offering external support to minority Social Democratic governments, and have felt badly burned by the experience. This has happened in both Sweden and Denmark. In both countries, left parties have felt that they got little or nothing for their support and that the Social Democrats were able to successfully claim credit for policies that had been agreed in advance with the left parties and off-load responsibility for government failings onto them (Gade Interview, Olsen interview, Arvidsson interview). These parties see full inclusion in government as the only realistic option for the future and a similar lesson was drawn from their experience by left parties elsewhere (Lysbakken interview, Kox interview). The 'half-way house' represented by support party status generally leaves smaller (and sometimes newer) parties no better off than those who are able to become full-blown coalition partners (see Bale and Blomgren, 2008). There is no evidence that it has increased their legitimacy.

Legitimacy, of course, is inevitably dependent not just on governing performance but also on how that performance is presented. If there is one complaint that unites almost all radical left parties it is perhaps their sense of unfair treatment at the hands of the mass media. All of those politicians we interviewed felt that their parties face under-reporting (or exclusion), stereotyping and trivialisation. In Italy, where there are of course exceptional circumstances given Berlusconi's widespread media control, exclusion of the radical left from coverage was so bitterly felt that during the 2009 European election campaign leaders of the two communist parties were moved to stage protests outside the headquarters of state broadcaster, RAI, and to seek emergency meetings with its directors. In Finland, VAS leaders complained bitterly about a 'presidentialisation' of political debates with their party excluded from key television debates 'which were reduced to beauty contests between the two candidates for [the office of] prime minister'(Sirnö interview), and about a media 
tendency to act as an advocate for the Green Party over VAS, favouring interviews with Green politicians on environmental issues (Ojala interview). In Cyprus, by contrast, some AKEL leaders claimed that old-style anti-communism has largely ebbed in the mass media, as the party proves itself a serious government force.

Ironically, in Ireland, media praise for the competence and personal qualities of radical left ministers perhaps exacerbated tensions between those ministers and some activists, by suggesting that they would have promising careers as members of the bigger social democratic option if they could jettison a small and vote-losing party that was holding them back; and, indeed, following Irish DL's merger with Labour, two of its four parliamentary deputies went on to become Labour Party leaders. In Finland, also, VAS leader and Finance Minister Suvi-Anne Siimes received generally warm media coverage; but left her party, denouncing it as 'ungovernable', shortly after it returned to opposition in 2003 (Dunphy, 2007). In Sweden, a high media profile for former leader Gudrun Schyman, who abandoned the Left Party to found a rival feminist platform in 2004 , led to fears that the party would be badly damaged (Arvidsson interview).

Of course, left parties do not (and indeed cannot) always help themselves in this respect, with their traditions of internal democracy and heartfelt idealism leaving them vulnerable to journalists trained to look for splits and spats. The latter have always been a feature of left politics and may become all the more glaring with government office.

\section{Conclusion}

As the broad left in general becomes more fragmented and pluralist, government participation by radical left parties is becoming more commonplace. Many of those parties - including Die Linke in Germany, for which participation in federal government may still be a distant prospect - see participation as a logical step forward, marking their full acceptance as legitimate players in the game of democratic politics. This legitimacy is itself an achievement. Other important successes for the radical left would include: halting (or slowing) the march of neo-liberalism; achieving implementation of cornerstone policies; involving new social and political actors - for instance, social movements - in a new relationship to centres of power; and combating the influence of the far right. However, government participation also involves challenges and pitfalls for small, radical parties. For the left, these include: possible 'theft' of popular policies and of the credit for policy implementation by the larger, social democratic coalition partners; loss of identity - and consequently of voters and members - to the social democrats and other partners; disruption to party unity and activism as members become disillusioned with the pace of change; the danger of being portrayed in the media as irresponsible and amateurish if the party tries to be 'in government' but not 'of government'; and the danger of party atrophy.

Our analysis suggests that few radical left parties wish to stand aside from the game of coalition politics. Moreover, they approach the problems and difficulties we have outlined with open eyes. Our interviews with party leaders revealed, time and time again, that they are fully aware that government participation may involve painful policy compromises and even short-to-medium term electoral losses; but that 
they see no credible alternative to government participation and regard its promise of increased legitimacy and the potential to influence policy away from a more rightwing course as worthwhile compensatory goals. Radical left parties, for the most part however, have additional goals which the 'policy, office, votes' triad may not take full cognizance of. Chief amongst these goals are the maintenance of a credible socialist or anti-capitalist ideological vision that can inspire members and supporters and lend credibility to the party's claim to be vehicle of long-term societal transformation, and the maintenance of party unity. Both imply limits to policy compromise although what those limits may be is influenced by 'newness' and lack of experience in many cases. (For a discussion of the importance of organizational and ideological 'newness' in assessing the performance of newly governing parties in general, see Deschouwer, 2008).

The evidence from our interviews is that key leaders and strategists within left parties, having studied each other's experiences and shared views and opinions, are already learning a number of tentative lessons. First, that it may pay left parties to negotiate a detailed and concrete government programme that can be referred to, as opposed to a vague and open-ended agreement that can be more easily manipulated by the larger parties. Second, that selling government compromises to the party membership is easier if serious attention is paid to questions of party organisation and communications. Third, that there is a need to keep key social groups - for example, trade unions - on board. Fourth, that effective government participation, especially in a media-driven age, may require strong leadership and party discipline: left parties with strong traditions of maximum internal party democracy may - like the Greens before them - experience a jolt to their party culture. Finally, that approaching coalition from a position of electoral growth is always preferable to entering government after a set-back, with its attendant loss of morale and direction. 


\section{Appendix One: List of interviews}

Structured face-to-face interviews of between one and two hours duration were held, with either one or both authors present. Interviews followed a standardised list of around twenty questions, which were not notified to interviewees in advance, with follow-up questions and discussion. With the consent of all interviewees, they were recorded. In almost all cases, they took place in either party headquarters or in parliament. Interviewees were selected to give a balance where possible between: parliamentary leaders and headquarters staff; public faces of the party and those involved in internal organizational work, including behind-the-scenes negotiations; top ranking leaders and second-tier politicians.

\section{Cyprus:}

Stavros Evagorou, Progressive Party of Working people (AKEL) Central Committee secretary for economic and social affairs, Nicosia, 4 May 2004

Yiannakis Colocassides, AKEL CC secretary for party education, Nicosia, 5 May 2004

Nicos Katsourides, AKEL parliamentary leader, editor of party newspaper, and CC member, Nicosia, 5 May 2004

Andros Kiprianou, AKEL CC secretary for internal party affairs, MP, Nicosia, 4 May 2004

Vera Polycarpou, international secretary of AKEL, Nicosia, 4 December 2003

Venizelos Zanetos, AKEL CC secretary for party organisation, 4 May 2004

Denmark:

Jens Andersen, assistant to the General Secretary of the Socialist People's Party (SF), Copenhagen, 6 June 2005

Trine Bendix, ex-Vice Chair of SF, Copenhagen, 21 June 2005

Miriam Feilberg, International Committee, SF, Nicosia, 5 December 2003 and Copenhagen, 20 June 2005 (interviewed twice)

Steen Gade, MP from 1981-99, full-time SF cadre, Copenhagen, 20 June 2005

Holger Nielsen, Chairman of SF (1991-2005), Copenhagen, 21 June 2005

Pia Olsen, SF Party Board member, Copenhagen, 21 June 2005

Finland:

Paavo Arhinmaki, Chair Left Youth, member of Left Alliance (VAS) Board, Helsinki, 6 September 2004

Pekka Hynonen, VAS international secretary, Nicosia, 6 December 2003 and Helsinki, 6 September 2004 (interviewed twice)

Jarmo Linden, policy advisor to VAS government ministers, Chair of committee drafting 2007 VAS party programme, Helsinki, 6 September 2004

Outi Ojala, MP, member of VAS Board, Helsinki, 8 September 2004

Suvi-Anne Siimes, MP, Leader of VAS, Helsinki, 7 September 2004

Minna Sirnio, MP, deputy leader of VAS, 7 September 2004

France: 
Unnamed official (requested anonymity), French Communist Party (PCF), Nicosia, 3 December 2003

Ireland:

Peter Connell, formerly of Dublin Regional Council, Democratic Left (DL), Dublin, 5 August 2003

Deirdre O'Connell, formerly Chair of Dublin South-Central DL, Dublin, 6 August 2003

Paddy Gillan, formerly editor of DL: party journal, Dublin, 7 August 2003

Italy:

Cinzia Palazzolo, Party of Italian Communists (PdCI), Nicosia, 5 December 2003

Jacopo Venier, Head of International Department, PdCI, Nicosia, 5 December 2003

Netherlands:

Harry van Bommel, MP, member of Socialist Party (SP) Board, The Hague, 29

August 2005

Hans van Heijningen, General Secretary of SP, Amsterdam, 29 August 2005

Agnes Kant, MP, SP Board member, The Hague, 30 August 2005

Tiny Kox, SP leader in the Dutch Senate, The Hague, 30 August 2005

Ingrid de Leeuw, member of SP Board, The Hague, 1 September 2005

Renske Leijten, Red Youth leader, member of SP Board, the Hague, 1 September 2005

Henk van der Wach, veteran founder member of SP, trade union activist, Rotterdam, 2 September 2005

Norway:

Knut Heidar, Professor of Politics at the University of Oslo (non-party), Oslo, 2 April 2006

Audun Lysbakken, Deputy Leader, Socialist Left Party (SV), Oslo, 4 April 2006

Jan-Egil Nyland, career civil servant (non-party), Oslo, 4 April 2006

Dag Seierstad member of SV leadership, Nicosia, 5 December 2003

Bard-Vegar Solhjell, former SV party secretary, Oslo, 4 April 2006

Inga Marte Thorkildsen, MP, Oslo, 3 April 2006

Sweden:

Hans Arvidsson, party worker for Left Party (V), Stockholm, 29 April 2003

Ulla Hoffman, MP and acting joint leader of V, Stockholm, 29 April 2003

Ann-Marie Ogalde, international secretary of V, Nicosia, 7 December 2003

Gudrun Schyman, then leader of V, Stockholm, 29 August 2001

Pernilla Zethraeus, Party Secretary of V, Stockholm, 29 April 2003

\section{References}


Bale, Tim and Bergman, T. (2006), 'Captives no longer, but servants still? Contract Parliamentarianism and the new minority governments in Sweden and New Zealand', Government and Opposition 41 (3): 422-449.

Bale, Tim and Blomgren, Magnus (2008), 'Close but no cigar? Newly governing and nearly governing parties in Sweden and New Zealand', in Kris Deschouwer (ed), Newly Governing Parties: in Power for the First Time. London: Routledge.

Bale, Tim and Dunphy, Richard (2006), 'In From the Cold? Left Parties as Normal Rather Than Niche Players in the Game of Government', paper presented to the PSAsponsored conference on radical left parties, University of Sussex, September.

Bolleyer, Nicole (2007), 'Small parties: From party pledges to government policy', West European Politics 30 (1): 121-147.

Bolleyer, Nicole (2008), 'The Organizational costs of public office' in Deschouwer, Kris (ed.), New Parties in government: in power for the first time: London: Taylor and Francis.

De Lange, Sarah (2007), From Pariah to Power. The Government Participation of Radical Right-Wing Populist Parties in West European Democracies ( $\mathrm{PhD}$ thesis, University of Antwerp).

Deschouwer, Kris (2008), 'Comparing Newly Governing Parties', in Deschouwer, Kris (ed.), New Parties in government: in power for the first time: London: Taylor and Francis.

Dunphy, Richard (1998), 'A Group of Individuals Trying to Do their Best: the Dilemmas of Democratic Left'. Irish Political Studies 13:50-75.

Dunphy, Richard (2007), 'In search of an identity: Finland's Left Alliance and the experience of Coalition Government', Contemporary Politics 13 (1): 37-55.

Dunphy, Richard and Bale, Tim (2007), 'Red Flag Still Flying: Explaining AKEL Cyprus's Communist Anomaly', Party Politics 13 (3): 287-304.

Hough, Dan and Verge, Tania (2009), 'A Sheep in Wolf's Clothing or a Gift from Heaven? Left-Left Coalitions in Comparative Perspective', Regional and Federal Studies, 19 (1): 37-55.

Kertzer, David I. (1996), Politics and Symbols: the Italian Communist Party and the Fall of Communism: New Haven and London: Yale University Press.

March, Luke and Mudde, Cas (2005), 'What Left of the Radical Left? The European Radical Left After 1989: Decline and Mutation', Comparative European Politics 3: 23-49.

Marijnissen, Jan (2008), 'SP's new course will be more controversial', www.international.sp.nl/bericht/23931/080311-

sps_new_course will be more controversial.html accessed on 14 March 2008. Müller, Wolfgang and Strøm, Kaare (eds) (1999), Policy, Office or Votes? How Political Parties in Western Europe Make Hard Decisions. Cambridge: Cambridge University Press.

Socialist Party of the Netherlands (2007), Informal Conference of Left Parties, Oss, The Netherlands, 14 July 2007.

Szarka, J. (1999), 'The Parties of the French "Plural Left": an Uneasy

Complementarity', West European Politics 22 (4):20-37.

Van Spanje, Joost (2007), 'Pariah Parties and Political Exclusion', EUI Review, Winter, 35-6. 
Strøm, Kaare, Budge, Ian, and Laver, Michael J. (1994), 'Constraints on Cabinet Formation in Parliamentary Democracies', American Journal of Political Science May 1994: 303-35. 